Int. J. Electrochem. Sci., 13 (2018) 2969 - 2985

International Journal of

ELECTROCHEMICAL

SCIENCE

Www.electrochemsci.org

\title{
Effect of Electrochemical Bath Composition on the Preparation of Ni-W-Fe-P Amorphous Alloy
}

\author{
Josiane Dantas Costa ${ }^{1}$, Mikarla Baía de Sousa ${ }^{1}$, José Jaílson Nicácio Alves ${ }^{1}$, Bianca de Oliveira \\ Evaristo $^{2}$, Raíssa Alves Queiroga ${ }^{2}$, Aureliano Xavier dos Santos ${ }^{2}$, Theophilo Moura Maciel ${ }^{2}$, \\ Ana Regina Nascimento Campos ${ }^{3}$, Renato Alexandre Costa de Santana ${ }^{3 *}$, Shiva Prasad ${ }^{3}$ \\ ${ }^{1}$ Department of Chemical Engineering, Federal University of Campina Grande, Av. Aprígio Veloso, \\ 882, 58429-970 Campina Grande, Brazil \\ ${ }^{2}$ Department of Mechanical Engineering, Federal University of Campina Grande, Av. Aprígio Veloso, \\ 882, 58429-140 Campina Grande - PB, Brazil \\ ${ }^{3}$ Department of Biology and Chemistry, Federal University of Campina Grande, R. Olho D' Água da \\ Bica, S. N., 58175-000 Cuité-Pb, Brazil \\ *E-mail: renatoacs@ufcg.edu.br
}

doi: $10.20964 / 2018.03 .36$

Received: 31 October 2017 / Accepted: 19 December 2017 / Published: 5 February 2018

The effect of nickel sulfate and sodium tungstate concentrations in an electrolytic bath on the process of obtaining the Ni-W-Fe-P alloy in the presence of a complexing agent and at high $\mathrm{pH}$ is investigated in the present work. The full $2^{2}$ factorial planning points plus two central points are used for the development of the work. For this study, within the range of the proposed variables, the optimum concentrations found were $0.02 \mathrm{M}$ nickel sulfate and $0.09 \mathrm{M}$ sodium tungstate, achieving a $497 \mathrm{HV}$ microhardness. The alloys obtained showed nodules and microcracks on their surfaces. It was observed that an increase in the sodium tungstate concentration in the bath favored the increase in the tungsten content, and this had a direct influence on the microhardness and corrosion resistance behavior. The best results were obtained with a tungsten content of approximately 18 at $\%$. Values of tungsten above 22 at $\%$ in the film favored the increase in internal tension, thus promoting a greater number of microcracks, and these caused a reduction in the microhardness and corrosion resistance. All the coatings were amorphous.

Keywords: Electrodeposition, tungsten alloys, experimental planning, optimization.

\section{$\underline{\text { FULL TEXT }}$}

(C) 2018 The Authors. Published by ESG (www.electrochemsci.org). This article is an open access article distributed under the terms and conditions of the Creative Commons Attribution license (http://creativecommons.org/licenses/by/4.0/). 